\title{
IN VIVO PROTECTIVE EFFECTS OF GALLIC ACID ISOLATED FROM PELTIPHYLLUM PELTATUM AGAINST SODIUM FLUORIDE-INDUCED OXIDATIVE STRESS IN RAT ERYTHROCYTES
}

\author{
Seyed Fazel NABAVI ${ }^{1}$, Solomon HABTEMARIAM ${ }^{2}$, Antoni SUREDA ${ }^{3}$, Akbar HAJIZADEH \\ MOGHADDAM $^{4,5}$, Maria DAGLIA ${ }^{6}$, and Seyed Mohammad NABAVI ${ }^{1}$ \\ Applied Biotechnology Research Center, Baqiyatallah University of Medical Sciences, Tehran, Iran ${ }^{1}$, Pharmacognosy \\ Research Laboratories, Medway School of Science, University of Greenwich, UK², Laboratori de Ciències de \\ l'Activitat Física, Departament de Biologia Fonamental i Ciències de la Salut, Universitat de les Illes Balears, Palma \\ de Mallorca, Illes Balears, Spain3, Department of Biology, Faculty of Basic Sciences, University of Mazandaran, \\ Babolsar, Iran ${ }^{4}$, Amol University of Modern Technologies, Amol, Iran ${ }^{5}$, Department of Drug Sciences, Medicinal \\ Chemistry and Pharmaceutical Technology Section University of Pavia, Pavia, Italy ${ }^{6}$
}

Received in January 2013

CrossChecked in January 2013

Accepted in June 2013

\begin{abstract}
Gallic acid has been identified as an antioxidant component of the edible and medicinal plant Peltiphyllum peltatum. The present study examined its potential protective role against sodium fluoride (NaF)-induced oxidative stress in rat erythrocytes. Oxidative stress was induced by $\mathrm{NaF}$ administration through drinking water (1030.675 mg m $\mathrm{m}^{-3}$ for one week). Gallic acid at $10 \mathrm{mg} \mathrm{kg}^{-1}$ and $20 \mathrm{mg} \mathrm{kg}^{-1}$ and vitamin $\mathrm{C}$ for positive controls $\left(10 \mathrm{mg} \mathrm{kg}^{-1}\right)$ were administered daily intraperitoneally for one week prior to $\mathrm{NaF}$ administration. Thiobarbituric acid reactive substances, antioxidant enzyme activities (superoxide dismutase and catalase), and the level of reduced glutathione were evaluated in rat erythrocytes. Lipid peroxidation in NaF-exposed rats significantly increased (by $88.8 \%$ ) when compared to the control group $(p<0.05)$. Pre-treatment with gallic acid suppressed lipid peroxidation in erythrocytes in a dose-dependent manner. Catalase and superoxide dismutase enzyme activities and glutathione levels were reduced by NaF intoxication by $54.4 \%$, $63.69 \%$, and $42 \%(p<0.001 ; v s$. untreated control group), respectively. Pre-treatment with gallic acid or vitamin C significantly attenuated the deleterious effects. Gallic acid isolated from Peltiphyllum peltatum and vitamin $\mathrm{C}$ mitigated the $\mathrm{NaF}$-induced oxidative stress in rat erythrocytes.
\end{abstract}

KEY WORDS: antioxidant, catalase, haemolysates, reduced glutathione, superoxide dismutase

Fluoride and fluorinated compounds occur in water, foods, drugs, air (due to gaseous industrial waste), and are widely used as ingredients of toothpaste and agrochemical products (1). Acute high-level exposure to fluoride is rare and usually results from accidental contamination of drinking water. Moderate-level chronic exposure (above $1.5 \mathrm{mg} \mathrm{L}^{-1}$, the WHO guideline value for fluoride in water) is more common. It is well-known that chronic long-term exposure to high levels (both the Maximum Contaminant Level and Maximum Contaminant Level Goal for fluoride equal $4 \mathrm{mg} \mathrm{L}^{-1}$ ) of fluoride leads to dental and skeletal 
fluorosis (2). Since numerous scientific reports have documented fluoride-induced toxicity in living systems (3-5), the ever-increasing volume of fluoride-polluted drinking water has been one of the main sources of public concern (3). Recent studies have suggested that fluoride intoxication leads to the down-regulation of antioxidant enzymes (3), an increase in relative oxygen species (ROS), and oxidative stress (4). The prooxidantantioxidant imbalance caused by fluoride intoxication may lead to multi-organ dysfunctions (5). Excessive ROS production and/or diminished antioxidant defences have been implicated in cancer, diabetes, and cardiovascular diseases (6-8).

Over the last few decades, various laboratories worldwide have been in search of novel antioxidant compounds that could be used as nutritional and/or therapeutic agents. In our laboratory studies, one plant demonstrated increased antioxidant potential: Peltiphyllum peltatum (Torr.) Engl. [Synonyms Darmera peltata (Torr.) Voss; Saxifraga peltata (Torr. ex Benth.)], which belongs to the Saxifragaceae family (9). This plant is cultivated in Europe for its distinct ornamental features and is commonly known in many localities as Indian Rhubarb or Umbrella Plant. It is known to be edible and is used for medicinal purposes $(10,11)$. The extracts of its leaves possess potent radical scavenging effects, protect biological macromolecular molecules (e.g., DNA) from oxidative damage, and protect cultured cells from hydrogen peroxide $\left(\mathrm{H}_{2} \mathrm{O}_{2}\right)$-induced cell death (9). Subsequent studies on this plant revealed active antioxidant components such as gallic acid and a number of other related polyphenols $(12,13)$. The comparative antioxidant and prooxidant effects of gallic acid and the related compounds of $P$. peltatum have been assessed in vitro (12). Gallic acid is a ubiquitous natural product with various industrial applications including ink dyes, tanning products, and paper (14). Recent studies have documented that gallic acid and its esters [e.g., (-)-epi-gallocatechin-3-gallate] exert antioxidant, anticancer, antiviral, and many other biological effects (15-17). The cytoprotective properties of gallic acid in vitro have also been observed previously $(18,19)$.

In a previous study (20), we introduced a rat model of fluoride-induced oxidative damage. In order to continue our work on $P$. peltatum and validate the therapeutic potential of gallic acid from natural sources, the present study was designed to study the in vivo protective effect of gallic acid against oxidative damages in rat erythrocytes.

\section{MATERIALS AND METHODS}

\section{Chemicals}

Bovine serum albumin and protein quantification kits were purchased from ZiestChem Company (Tehran, Iran). Glacial acetic acid, 5,5-dithiobis(2nitrobenzoic acid), heparin, nitro blue tetrazolium chloride, potassium dihydrogen phosphate, reduced glutathione, sodium dihydrogen phosphate, sodium fluoride, trichloroacetic acid, thiobarbituric acid, hydrogen peroxide were purchased from SigmaAldrich chemical company (St Louis, MO, USA). All chemical reagents were of analytical grade.

\section{Isolation of gallic acid}

As a source for gallic acid, we used Peltiphyllum peltatum (Torr.), grown in our medicinal gardens. The isolation and identification of gallic acid from this plant has been described previously $(12,13)$.

\section{Animals}

The experiments were performed on 50 male Wistar rats ( 8 to 12 week-old, weight $200 \mathrm{~g}$ to $250 \mathrm{~g}$ ). Animal housing was maintained at $(24 \pm 2){ }^{\circ} \mathrm{C}$, $(60 \pm 5) \%$ humidity, and a $12 \mathrm{~h} \mathrm{light} / 12 \mathrm{~h}$ dark cycle. The animals were fed on a standard laboratory pellet diet purchased from the Pasture Institute (Tehran, Iran) and water was given ad libitum. The animals were allowed to adapt for two weeks before being used for experiments. All experiments were performed following guidelines from the "Principles of Laboratory Animals Care" (NIH Publication no. 85-23, revised 1996) (21). All efforts were made to minimize animal suffering and reduce the number of animals used.

\section{Study protocols}

The rats were randomly divided into five groups of 10 animals each. The control group received isotonic saline solution. One group received sodium fluoride $(\mathrm{NaF})$ at a dose of $1030.675 \mathrm{mg} \mathrm{m}^{-3}$ through drinking water for 7 days as described previously (1). The other three experimental groups were treated with gallic acid (10 mg kg $\mathrm{mg}^{-1}$ and $20 \mathrm{mg} \mathrm{kg}^{-1}$ body mass) or vitamin $\mathrm{C}$ (10 $\mathrm{mg} \mathrm{kg}^{-1}$ body mass) intraperitoneally for 7 days prior to $\mathrm{NaF}$ intoxication. The doses of the tested substances were based on a previous in vivo study (1). The rats were anaesthetised with ketamine $\left(60 \mathrm{mg} \mathrm{kg}^{-1}\right)$ and xylazine $\left(5 \mathrm{mg} \mathrm{kg}^{-1}\right)$, sacrificed $24 \mathrm{~h}$ after the final dose of $\mathrm{NaF}$, and the blood samples were 
collected from cardiac punctures into heparinized tubes.

\section{Preparation of haemolysates}

Blood samples were centrifuged at $1000 \mathrm{~g}$ for 15 min. After removing the upper layer, the packed erythrocytes were washed with $0.01 \mathrm{~mol} \mathrm{~L}^{-1}$ of phosphate buffer saline ( $\mathrm{pH} 7.4)$, and lysed by hypotonic phosphate buffer $\left(0.01 \mathrm{~mol} \mathrm{~L}^{-1}\right)$. Cell debris was removed through centrifugation at $3000 \mathrm{~g}$ for $15 \mathrm{~min}$. Blood haemolysates were collected and immediately used for biochemical analysis.

\section{Protein content analysis}

Bradford method (22) was used for total protein determination, while the Drabkin \& Austin method (23) was used to evaluate haemoglobin content.

\section{Measurement of erythrocytes lipid peroxidation}

The level of lipid peroxidation was assessed by measuring the levels of thiobarbituric acid reactive substance (TBARS) formation (24). Briefly, erythrocyte homogenates containing $1 \mathrm{mg}$ protein were mixed with trichloroacetic acid $(1 \mathrm{~mL}, 20 \%)$ and thiobarbituric acid $(2 \mathrm{~mL}, 0.67 \%)$. Reaction mixtures in microcentrifuge tubes were incubated for $1 \mathrm{~h}$ at $100{ }^{\circ} \mathrm{C}$. After cooling and removal of precipitate by centrifugation (1000g for $15 \mathrm{~min}$ ), absorbance was measured at $535 \mathrm{~nm}$ using appropriate blank controls. The extinction coefficient of malondialdehyde (MDA) was used for calculating the extent of lipid peroxidation.

\section{Measurement of superoxide dismutase activity}

The superoxide dismutase (SOD) activity of erythrocyte haemolysates was assessed by using method of Paoletti et al. (25). In this nitroblue tetrazolium-based assay, one unit of SOD activity is defined as the enzyme level required in inhibiting chromogen generation by $50 \%$.

\section{Measurement of catalase activity}

The enzymatic activity of erythrocyte lysates was examined following the method of Pari \& Latha (26). This assay is based on measuring catalase activity in transforming hydrogen peroxide $\left(\mathrm{H}_{2} \mathrm{O}_{2}\right)$ into water. Briefly, erythrocyte homogenates ( $5 \mu \mathrm{g}$ protein) were mixed with $\mathrm{H}_{2} \mathrm{O}_{2}\left(2.1 \mathrm{~mL}, 7.5 \mathrm{mmol} \mathrm{L}^{-1}\right)$ and enzymatic activity was monitored over $10 \mathrm{~min}$ using
UV absorbance at $25^{\circ} \mathrm{C}$. One unit of catalase activity was defined as the amount of enzyme that reduced $1 \mu \mathrm{mol}$ of $\mathrm{H}_{2} \mathrm{O}_{2}$ per minute.

\section{Measurement of reduced glutathione (GSH) levels}

GSH levels were measured using Ellman's colorimetric method (27). Trichloroacetic acid was added to erythrocyte haemolysates (containing $36 \mu \mathrm{g}$ protein) to precipitate the proteins. After removal of proteins by centrifugation $(12000 \mathrm{~g}, 5 \mathrm{~min})$, the supernatants containing GSH were mixed with 5, 5dithiobis 2-nitrobenzoic acid solution (Sigma-Aldrich chemical company, St Louis, MO, USA). Absorbances at $417 \mathrm{~nm}$ were measured for samples and GSH levels were calculated from standard GSH calibration curves.

\section{Statistical analysis}

Results are presented as mean \pm SD. Statistical analysis was carried out using a statistical package (SPSS 17.0 for Windows ${ }^{\circledR}$ ). Differences between group means were estimated using one-way analysis of variance followed by Duncan's multiple range tests. Results were considered statistically significant when $p<0.05$ or $p<0.01$.

\section{RESULTS AND DISCUSSION}

In order to obtain deeper insight into the therapeutic potential of gallic acid (and its source plant $P$. peltatum), the present study was designed to evaluate the in vivo antioxidant effects of the compound by using a rat model of NaF-intoxication.

The results have confirmed our working hypothesis that gallic acid extracted from P. peltatum is capable of protecting rat erythrocytes against NaF-induced oxidative damage. Through comparison with known antioxidant positive controls (vitamin C), the positive effect of gallic acid on $\mathrm{NaF}$-mediated lipid peroxidation, as well as on the level of antioxidant defences (superoxide dismutase, catalase and reduced glutathione), was proven. The extent of lipid peroxidation, expressed as TBARS levels in the erythrocytes of the treated groups and untreated controls, is shown in Figure 1. Exposure to $\mathrm{NaF}$ significantly increased the TBARS levels when compared to the control group $(p<0.001)$. Pretreatment with gallic acid ( $10 \mathrm{mg} \mathrm{kg}^{-1}$ and $20 \mathrm{mg} \mathrm{kg}^{-1}$ body mass) prior to $\mathrm{NaF}$ exposure resulted in a dose- 


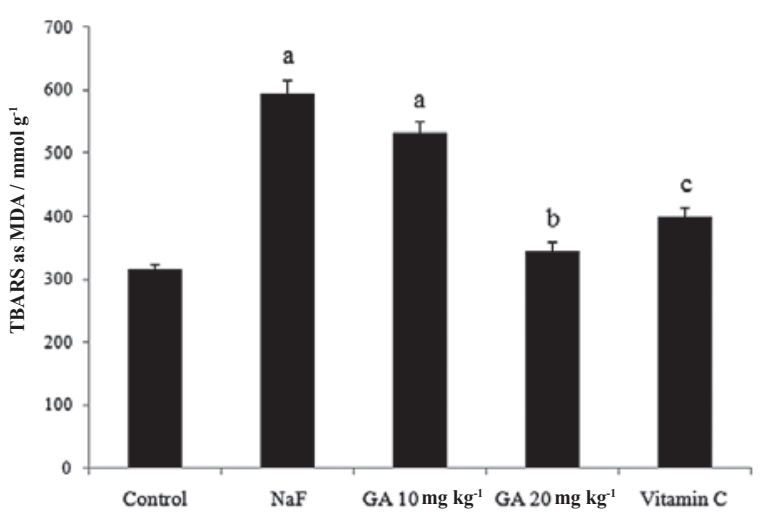

Figure 1 Effects of gallic acid and vitamin C on TBARS levels in erythrocytes of sodium fluoride-intoxicated rats. Data are mean $\pm S D$ values $(\mathrm{n}=10) ;{ }^{a} \mathrm{p}<0.001$ vs. control group, ${ }^{b} \mathrm{p}>0.05$ vs. control group, ${ }^{c} \mathrm{p}<0.01$ vs. control group.

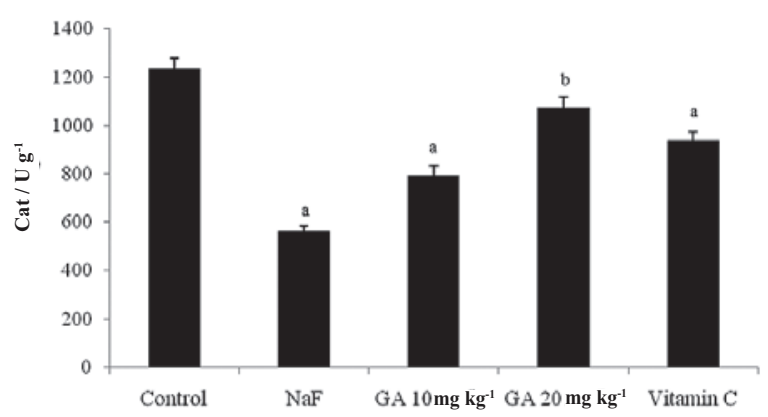

Figure 3 Effects of gallic acid and vitamin $C$ on catalase activity in erythrocytes of sodium fluoride-intoxicated rats. Data are mean $\pm S D$ values $(\mathrm{n}=10) ;{ }^{a} \mathrm{p}<0.001$ vs. control group, ${ }^{b} \mathrm{p}<0.01$ vs. control group, ${ }^{c}$ $\mathrm{p}<0.05$ vs. control group.

dependent reduction of TBARS levels in rat erythrocytes. At $20 \mathrm{mg} \mathrm{kg}^{-1}$ body mass, gallic acid completely reversed the $\mathrm{NaF}$-induced increase in TBARS levels ( $p<0.05 v$ s. control group). The positive control, vitamin C, tested at $10 \mathrm{mg} \mathrm{kg}^{-1}$ also ameliorated the NaF-induced rise in TBARS levels (Figure 1).

As shown in Figure 2 and 3, the activity profiles of rat erythrocyte superoxide dismutase and catalase were very similar. The two enzyme activities in erythrocytes significantly $(p<0.05)$ decreased in NaFexposed rats when compared to untreated control rats. Rats pre-treated with gallic acid appeared to have erythrocytes with higher levels of enzyme activity than the NaF-treated groups (Figure 2 and 3). At $20 \mathrm{mg} \mathrm{kg}^{-1}$, the protective role of gallic acid on SOD activity was comparable to ascorbic acid, whereas the

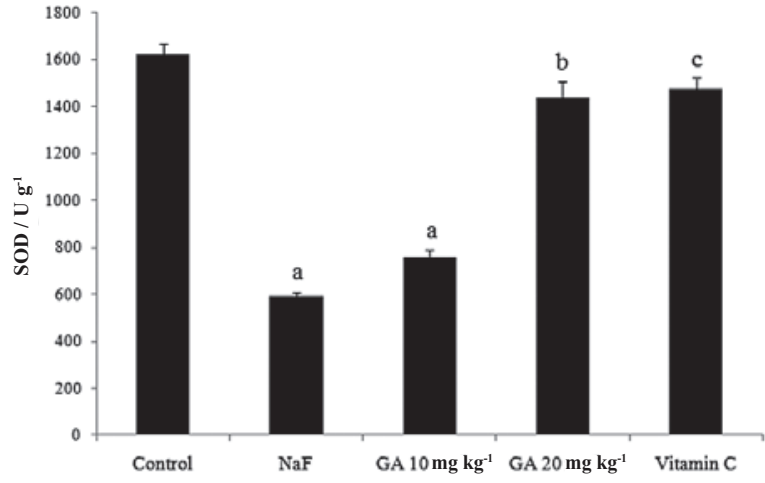

Figure 2 Effects of gallic acid and vitamin C on SOD activity in erythrocytes of sodium fluoride-intoxicated rats. Data are mean $\pm S D$ values $(\mathrm{n}=10)$; ${ }^{a} \mathrm{p}<0.001$ vs. control group, ${ }^{b} \mathrm{p}<0.01$ vs. control group, ${ }^{c} \mathrm{p}<0.05$ vs. control group.

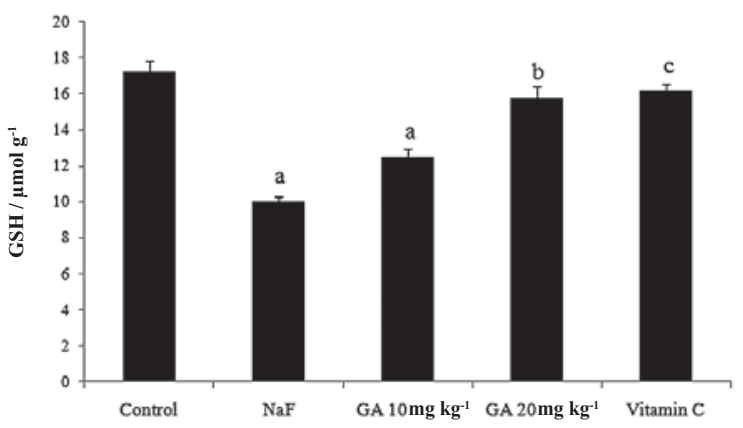

Figure 4 Effects of gallic acid and vitamin C on GSH levels in erythrocytes of sodium fluoride-intoxicated rats. Data are mean $\pm S D$ values $(\mathrm{n}=10) ;{ }^{a} \mathrm{p}<0.001$ vs. control group, ${ }^{b} \mathrm{p}<0.01$ vs. control group, ${ }^{c} \mathrm{p}<0.05$ vs. control group.

effect of gallic acid on catalase activity was more pronounced than for vitamin $\mathrm{C}$ (Figure 2 and 3 ).

GSH levels in rat erythrocytes from the NaFtreated group were significantly lower than in the untreated control groups (Figure 4). Administration of gallic acid before $\mathrm{NaF}$ intoxication mitigated the reduced GSH levels in a dose dependent manner. As with the remaining antioxidant parameters studied, the positive control vitamin $C$ was also able to reverse the in vivo prooxidative effect of $\mathrm{NaF}$ (Figure 4).

Previous reports on the protective effects of gallic acid are ambiguous. Hsieh et al. (28) found that, under in vitro conditions, gallic acid protected human erythrocytes from oxidative damage. In contradiction to this finding, Ximenes et al. (29) suggested that gallic acid is prooxidative in cellular systems and could 
exacerbate the drug-induced prooxidative damage in human erythrocytes. The prooxidative effect of gallic acid at the molecular level (30) and oxidative-based induction of cell death in cancer cells $(31,32)$ have also been documented. Furthermore, the in vitro induction of cancer cells through the generation of ROS has also been linked to the depletion of antioxidant defences (32). Previous studies have also suggested that fluoride intoxication leads to excessive ROS generation, and inhibition of endogenous antioxidant enzymatic activities (33), increased lipid peroxidation, and cell injury (34).

Results of the present study are in good agreement with previous reports and confirm that $\mathrm{NaF}$ administration increased levels of lipid peroxidation and reduced SOD and catalase activities. Furthermore, we found that glutathione levels in erythrocytes diminished after $\mathrm{NaF}$ exposure, suggesting an induction of oxidative stress. These findings, together with the results obtained for the positive control, vitamin $\mathrm{C}$, were in agreement with our previous study (20) where in vivo amelioration of NaF-mediated oxidative stress was recorded in curcumin pre-treated rats. Our finding that gallic acid effectively protected rat erythrocytes suggests that the antioxidant effect of the compound at the tested dosage in vivo was more prevalent than its prooxidative effects. The ameliorative effect of gallic acid on lipid peroxidation in vivo was also in agreement with other studies $(35,36,37,38)$. Although Li et al. (36) revealed the potential of gallic acid in increasing the GSH/oxidized glutathione (GSSG) ratio in senescence-accelerated mice, our result appears to be the first evidence on the beneficial effect of gallic acid on in vivo NaF-mediated oxidative stress in rat erythrocytes.

\section{CONCLUSION}

The use of fluorine in common everyday products such as toothpaste, drugs, and agrochemicals implies that unwanted side effects are practically inevitable. Our finding that gallic acid mitigates such adverse effects on rat erythrocytes underscored its protective or therapeutic potential. However, more studies are needed to investigate the molecular mechanism by which the in vivo protective effect of gallic acid against $\mathrm{NaF}$ intoxication is exerted (e.g., the up-regulation of microRNAs). Also, future studies should focus on the possible effect of other $P$. peltatum active compounds and their pharmacokinetics.

\section{REFERENCES}

1. Nabavi SM, Nabavi SF, Eslami S, Moghaddam AH. In vivo protective effects of quercetin against sodium fluorideinduced oxidative stress in the hepatic tissue. Food Chem 2012;132:931-5. doi: 10.1016/j.foodchem.2011.11.070

2. Carton RJ. Review of the 2006 United States National Research Council report: fluoride in drinking water. Fluoride 2006;39:163-72.

3. Vani ML, Reddy KP. Effects of fluoride accumulation on some enzymes of brain and gastrocnemius muscle of mice. Fluoride 2000;33:17-26.

4. Ghosh D, Das Sarkar S, Maity R, Jana D, Das UB. Testicular toxicity in sodium fluoride treated rats: association with oxidative stress. Reprod Toxicol 2002;16:385-90. PMID: 12220599

5. Chlubek D. Fluoride and oxidative stress. Fluoride 2003;36:217-28.

6. Storz P. Reactive oxygen species-mediated mitochondria-tonucleus signaling: a key to aging and radical-caused diseases. Sci STKE 2006;332:re3. doi: 10.1126/stke.3322006re3

7. Montezano AC, Touyz RM. Molecular mechanisms of hypertension-reactive oxygen species and antioxidants: a basic science update for the clinician. Can J Cardiol 2012;28:288-95. doi: 10.1016/j.cjca.2012.01.017

8. Fatehi-Hassanabad Z, Chan CB, Furman BL. Reactive oxygen species and endothelial function in diabetes. Eur $\mathrm{J}$ Pharmacol 2010;636:8-17. doi: 10.1016/j. ejphar.2010.03.048

9. Habtemariam S, Jackson C. Antioxidant and cytoprotective activity of leaves of Peltiphyllum peltatum (Torr.) Engl. Food Chem 2007;105:498-503. doi: 10.1016/j. foodchem.2007.03.073

10. Fern K. Plants for a future: Edible \& Useful plants for a healthier world. Hampshire (UK): Permanent Publications; 1997.

11. Moerman DE. Native American Ethnobotany: An Ethnobotanical Dictionary. Portland (OR): Timber Press; 1998.

12. Habtemariam S. Activity-guided isolation and identification of antioxidant components from ethanolic extract of Peltiphyllum peltatum (Torr.) Engl. Nat Prod Commun 2008:3:1321-4.

13. Habtemariam S. Methyl-3-O-methyl gallate and gallic acid from the leaves of Peltiphyllum peltatum: isolation and comparative antioxidant, prooxidant, and cytotoxic effects in neuronal cells. J Med Food 2011;14:1412-8. doi: 10.1089/ jmf. 2010.0257

14. Eslami AC, Pasanphan W, Wagner BA, Buettner GR. Free radicals produced by the oxidation of gallic acid: An electron paramagnetic resonance study. Chem Cent J 2010;4:15-9. doi: 10.1186/1752-153X-4-15

15. Sohi KK, Mittal N, Hundal MK, Khanduja KL. Gallic acid, an antioxidant, exhibits antiapoptotic potential in normal human lymphocytes: a Bcl-2 independent mechanism. J Nutr Sci Vitaminol 2003;49:221-7. PMID: 14598907

16. Tachibana H, Koga K, Fujimura Y, Yamada K. A receptor for green tea polyphenol EGCG. Nat Struct Mol Biol 2004;11:3801. PMID: 15024383

17. Sameermahmood Z, Raji L, Saravanan T, Vaidya A, Mohan V, Balasubramanyam M. Gallic acid protects RINm5F b-cells from glucolipotoxicity by its antiapoptotic and insulin- 
secretagogue actions. Phytother Res 2010;24:S83-94. PMID 19610036

18. Hansi PD, Stanely PP. Cardioprotective effect of gallic acid on cardiac troponin- $T$, cardiac marker enzymes, lipid peroxidation products and antioxidants in experimentally induced myocardial infarction in Wistar rats. Chem Biol Interact 2009;179:118-24. doi: 10.1016/j.cbi.2008.12.012

19. Li T, Zhang X, Zhao X. Powerful protective effects of gallic acid and tea polyphenols on human hepatocytes injury induced by hydrogen peroxide or carbon tetrachloride in vitro. J Med Plant Res 2010;4:247-54.

20. Nabavi SF, Nabavi SM, Abolhasani F, Moghaddam AH, Eslami S. Cytoprotective effects of curcumin on sodium fluoride-induced intoxication in rat erythrocytes. Bull Environ Contam Toxicol 2012;88:486-90. doi: 10.1007/ s00128-011-0495-5

21. National Institutes of Health (NIH). Guide for the Care and Use of Laboratory Animals. NIH publication 85-23, revised 1996. Bethesda (MD): NIH; 1996.

22. Bradford MM. A rapid and sensitive method for the quantitation of microgram quantities of protein utilizing the principle of protein-dye binding. Anal Biochem 1976;72:248 54. doi: 10.1016/0003-2697(76)90527-3

23. Drabkin DL, Austin JH. Spectrophotometric studies V. a technique for the analysis of undiluted blood and concentrated hemoglobin solutions. J Biol Chem 1935;112:105-15.

24. Draper HH, Hadley M. Malondialdehyde determination as index of lipid peroxidation. Method Enzymol 1990;186:42131. PMID: 2233309

25. Paoletti F, Aldinucci D, Mocali A, Caparrini A. A sensitive spectrophotometric method for the determination of superoxide dismutase activity in tissue extracts. Anal Biochem 1986;154:536-41. doi: 10.1016/00032697(86)90026-6

26. Pari L, Latha M. Protective role of Scoparia dulcis plant extract on brain antioxidant status and lipid peroxidation in STZ diabetic male Wistar rats. BMC Complem Altern Med 2004:4:4-16. doi: 10.1186/1472-6882-4-16

27. Ellman GL. Tissue sulphydryl group. Arch Biochem Biophys 1959;82:70-7. PMID: 13650640

28. Hsieh CL, Yen GC, Chen HY. Antioxidant activities of phenolic acids on ultraviolet radiation-induced erythrocyte and low density lipoprotein oxidation. J Agric Food Chem 2005;53:6151-5. doi: 10.1021/jf050707a

29. Ximenes VF, Lopes MG, Petrônio MS, Regasini LO, Silva DH, Da Fonseca LM. Inhibitory effect of gallic acid and its esters on 2, 2'-azobis(2-amidinopropane)hydrochloride (AAPH)-induced hemolysis and depletion of intracellular glutathione in erythrocytes. J Agric Food Chem 2010;58:535562. doi: $10.1021 / \mathrm{jf} 100233 \mathrm{y}$

30. Yoshino M, Haneda M, Naruse M, Htay HH, Iwata S, Tsubouchi R, Murakami K. Prooxidant action of gallic acid compounds: copper-dependent strand breaks and the formation of 8-hydroxy-2'-deoxyguanosine in DNA. Toxicol In Vitro 2002;16:705-9. doi: 10.1016/S0887-2333(02)000619

31. Chen HM, Wu YC, Chia YC, Chang FR, Hsu HK, Hsieh YC, Chen CC, Yuan SS. Gallic acid, a major component of Toona sinensis leaf extracts, contains a ROS-mediated anti-cancer activity in human prostate cancer cells. Cancer Lett 2009;286:161-71. doi: 10.1016/j.canlet.2009.05.040

32. You BR, Park WH. Gallic acid-induced lung cancer cell death is related to glutathione depletion as well as reactive oxygen species increase. Toxicol In Vitro 2010;24:1356-62. doi: 10.1016/j.tiv.2010.04.009

33. Ranjan R, Swarup D, Patra RC. Oxidative stress indices in erythrocytes, liver, and kidneys of fluoride-exposed rabbits. Fluoride 2009;42:88-93.

34. Liu GY, Chai CY, Li C. Fluoride causing abnormally elevated serum nitric oxide levels in chicks. Environm Toxicol Pharmacol 2003;13:199-204. doi: 10.1016/S13826689(03)00002-4

35. Punithavathi VR, Prince PSM, Kumar R, Selvakumari J. Antihyperglycaemic, antilipid peroxidative and antioxidant effects of gallic acid on streptozotocin induced diabetic Wistar rats. Eur J Pharmacol 2011;650:465-71. doi: 10.1016/ j.ejphar.2010.08.059

36. Li L, Ng TB, Gao W, Li W, Fu M, Niu SM, Zhao L, Chen RR, Liu F. Antioxidant activity of gallic acid from rose flowers in senescence accelerated mice. Life Sci 2005;77:23040. PMID: 15862607

37. Kim YJ. Antimelanogenic and antioxidant properties of gallic Acid. Biol Pharm Bull 2007;30:1052-5. doi: 10.1248/ bpb.30.1052

38. Nabavi SM, Habtemariam S, Nabavi SF, Sureda A, Daglia M, Moghaddam AH, Amani MA. Protective effect of gallic acid isolated from Peltiphyllum peltatum against sodium fluoride-induced oxidative stress in rat's kidney. Mol Cell Biochem 2013; 372 (1-2): 233-9 doi:10.1007/s11010-0121464-y 


\section{Sažetak}

ZAŠTITNI UČINCI GALNE KISELINE IZDVOJENE IZ PELTIPHYLLUM PELTATUM NA RAZINU OKSIDATIVNOG STRESA IZAZVANOG NATRIJEVIM FLUORIDOM U ERITROCITIMA ŠTAKORA

Galna kiselina u ranijim je istraživanjima potvrđena kao važna antioksidativna sastavnica jestive i ljekovite biljke Peltiphyllum peltatum. U ovome istraživanju ispitan je njen potencijalni zaštitni učinak protiv oksidativnog stresa izazvanog natrijevim fluoridom $(\mathrm{NaF}) \mathrm{u}$ eritrocitima štakora. Oksidativni stres izazvan je davanjem NaF eksperimentalnim životinjama putem vode za piće $\left(1030,675 \mathrm{mg} \mathrm{m}^{-3}\right)$ tijekom jednog tjedna. Galna kiselina životinjama je davana intraperitonealno u dozama $10 \mathrm{mg} \mathrm{kg}^{-1}$ i $20 \mathrm{mg} \mathrm{kg}^{-1} \mathrm{na}$ dan. Životinje iz pozitivno kontrolne skupine svaki su dan, osim NaF, intraperitonealno primale vitamin $\mathrm{C} \mathrm{u}$ dozi $10 \mathrm{mg} \mathrm{kg}^{-1}$. U eritrocitima štakora primjenom TBARS-testa izmjerene su razine lipidne peroksidacije, aktivnosti antioksidativnih enzima (superoksid dismutaze i katalaze) te razina reduciranoga glutationa. Lipidna peroksidacija u štakora izloženih NaF osjetno se povećala $(88,8 \%)$ u usporedbi s kontrolnom skupinom $(p<0,05)$. Prethodni tretman galnom kiselinom smanjio je razinu lipidne peroksidacije $\mathrm{u}$ eritrocitima, ovisno o dozi. Toksičnost $\mathrm{NaF}$ smanjila je aktivnost enzima katalaze i superoksid dismutaze i razine glutationa za 54,4 \%, 63,69 \%, odnosno $42 \%$ ( $p<0,001$; u usporedbi s kontrolnom skupinom). Dobiveni rezultati upućuju na pozitivne učinke predobrade štakora galnom kiselinom izoliranom iz Peltiphyllum peltatum i vitaminom $\mathrm{C}$ na razinu oksidativnog stresa izazvanog natrijevim fluoridom $\mathrm{u}$ eritrocitima štakora.

KLJUČNE RIJEČI: antioksidansi, hemolizati, katalaza, reducirani glutation, superoksid dismutaza

\section{CORRESPONDING AUTHOR:}

Seyed Fazel Nabavi

Applied Biotechnology Research Center, Baqiyatallah University of Medical Sciences

Tehran, Iran, P.O. Box 19395-5487

E-mail: Nabavisf@gmail.com 